\title{
The Chevroches zodiacal cap and its Burgundy relations
}

\author{
Frédéric Devevey ${ }^{1}$, Christian Vernou ${ }^{2}$ and Aurélie Rousseau ${ }^{1}$ \\ ${ }^{1}$ INRAP, CNRS UMR 6249 \\ Rue Aristide Berges, 21800 Sennecey-les-Dijon, France \\ email: frederic.devevey@inrap.fr \\ email: archeorely@yahoo.fr \\ ${ }^{2}$ Musée Archéologique de Dijon \\ Rue Docteur Maret, 21000 Dijon, France \\ email: cvernou@ville-dijon.fr
}

\begin{abstract}
The excavation of an unexplored secondary agglomeration in Chevroches (France), from 2001 to 2002 has led to the discovery of a bronze dome of a type unknown in the Ancient world. It is inscribed with three lines in Greek transcribing Egyptian and Roman months, and the twelve signs of the Zodiac. This paper presents the first observations and some other finds from similar objects in Burgundy.
\end{abstract}

Keywords. Burgundy, mechanisms, Zodiac, astrology

\section{Introduction}

The Gallo-Roman site of Chevroches is located in the North West of the region of Burgundy in the Nièvre department (Fig. 1). During the Roman period, the site was part of the Eduens' territory. Their former celtic capital, Bibracte (Mont Beuvray) became Augustodunum (Autun). Chevroches turns out to be a previously unknown small GalloRoman town that extended over four hectares.

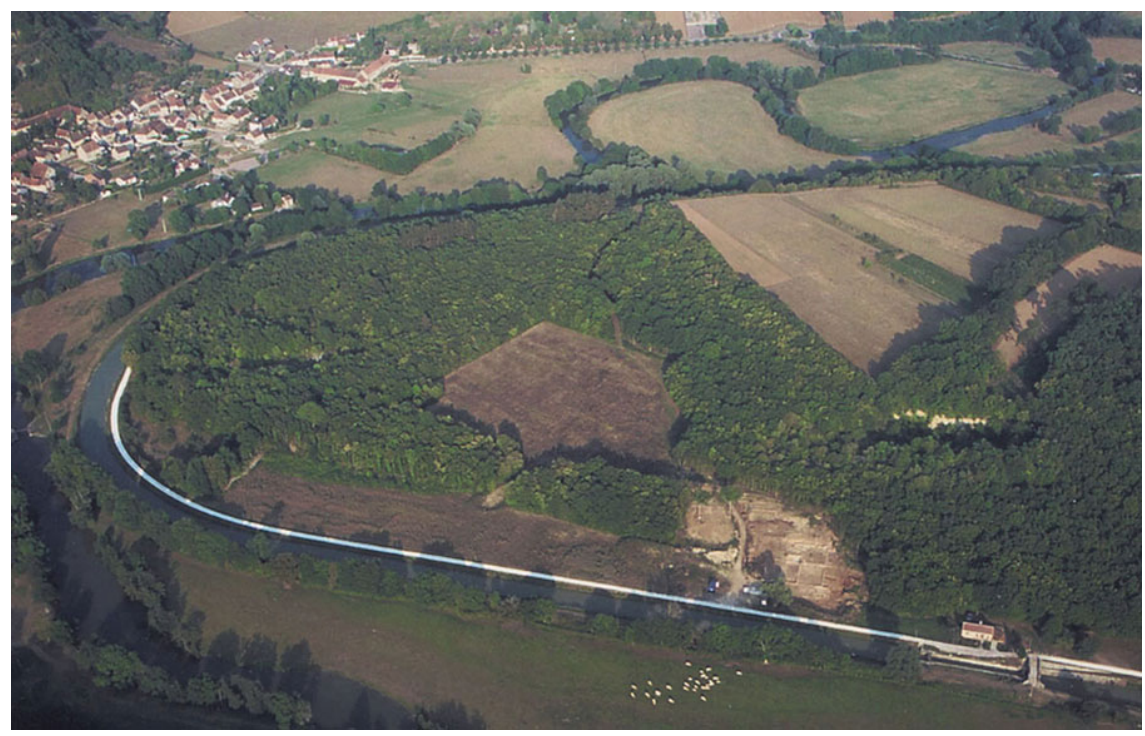

Figure 1. Aerial view of the archaeological site of Chevroches. (C) F. Devevey (2002). 
The site is very rich, as the Roman occupation lasted from the second quarter of the 1st century until the 5th century. Iron and bronze metalworking was an important activity during the 4th century and was organised by large workshops installed in small zones delineated by streets. Many noteworthy elements of furniture made of bronze, iron or lead have been discovered: tools, domestic elements, harnesses, bars and scrap from the forge, elements of finery and even a decorative element of an openwork sheath (Fig. 2).

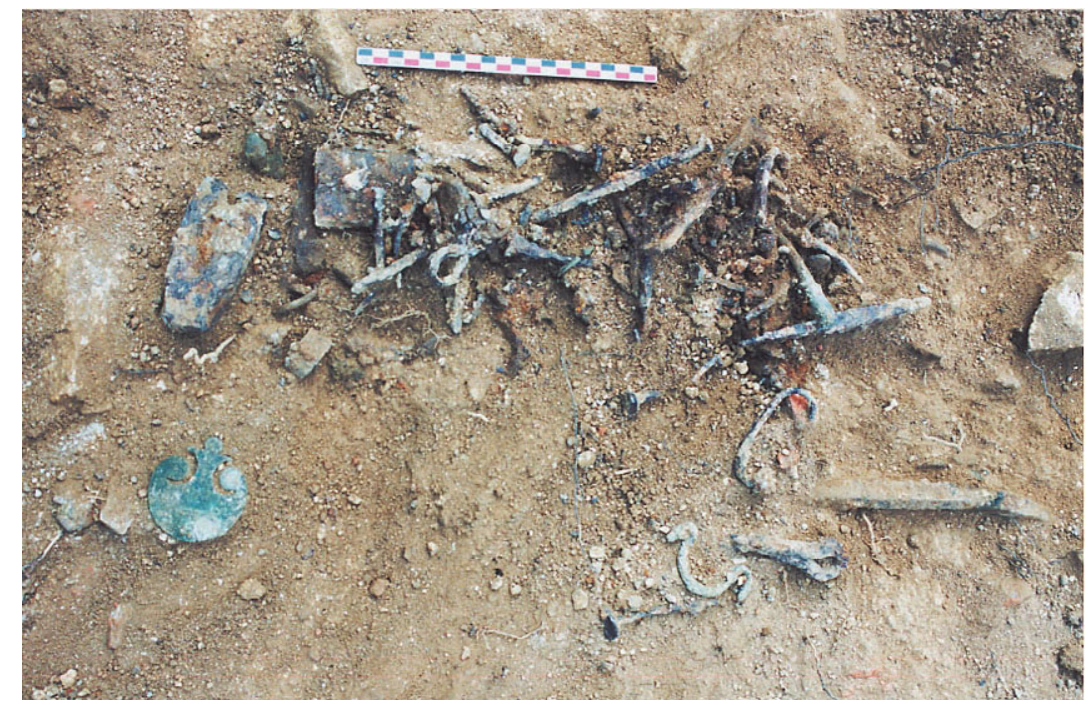

Figure 2. Zenithal view of area 1020 where the disc was discovered. (c) INRAP (2001).

Chevroches has become one of the most important archaeological sites uncovered by preventive excavations in the region (Devevey 2005).

A rich collection of objects originating from metallic deposits is preserved, with the financial help from the Archaeological Museum of Dijon and from the French Ministry of Culture (SRA Bourgogne).

The restoration team of the laboratory of metal archaeology at Jarville-Nancy discovered that an object, first classified as a decorative phaleræ (of a harness?), was in fact a particularly rare "scientific item". An initial analysis of this enigmatic piece is provided by Devevey et al. (2006).

\section{Description of the disc}

The piece is a curved disc which is divided into 12 equal sectors, and in each sector one can read three layered series of engraved words, all in Greek letters (Fig. 3a):

- the external line corresponds to the 12 Egyptians months;

- the median line states the 12 signs of the Zodiac in the dative case;

- the inner line presents the 12 Roman months, see Fig. 3b.

Most of the words are abbreviated. We can start the reading of this curved disc by Thoth, the first Egyptian month, which begins on our 28th day of August (or 29 for leap years). This object doesn't consider the 5 epagomenal days (6 for leap years since the Julian calendar reform). The civic Egyptian calendar counted regular months of 30 days, which had the consequence of adding 5 to 6 days to the end of each year. Hence, the concurrence between Roman and Egyptian months remains approximate (see Fig. 4). 

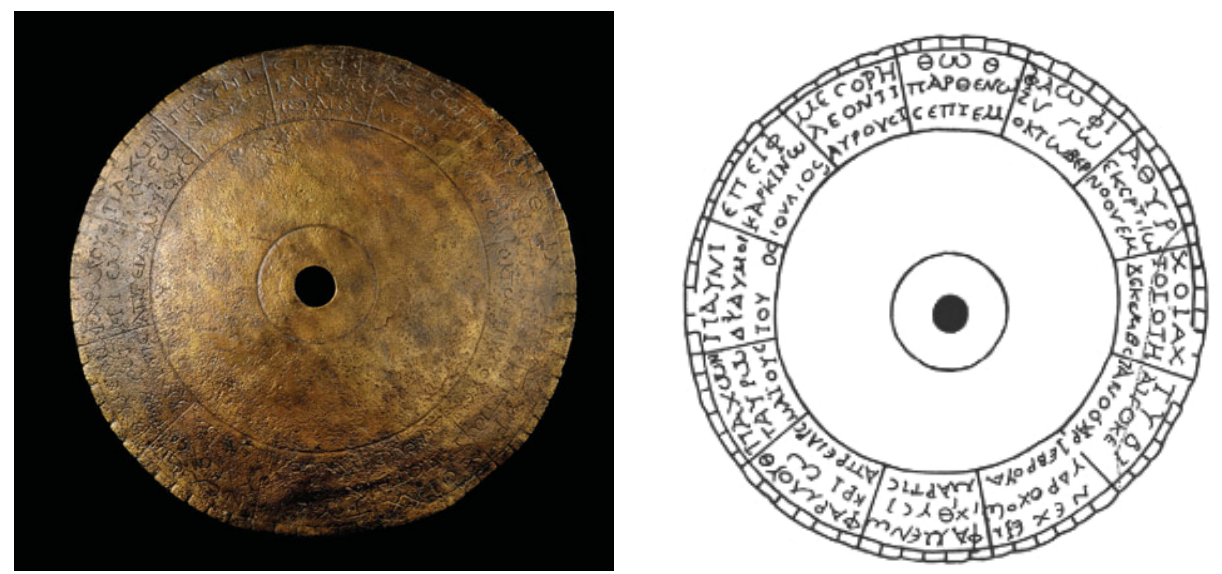

Figure 3. (Left) The disc of Chevroches (c) INRAP 2005). (Right) Graphical sketch (C) C. Magister-Vernou/MAD 2006).

\section{The manufacturing process}

It is interesting to try a restitution of the fabrication process :

- An artisan first manufactured the form of the curved disc by hammering out a bronze slab (around $100 \mathrm{~mm}$ in diameter), giving it its rounded aspect. (Fig. 5);

- An experienced engraver then chiseled three approximate concentric circles. The exterior circle is the least well-preserved. It is deleted in 2 places (abrasion?, see Fig. 5). A circular hole of $5 \mathrm{~mm}$ was pierced through the top of the object. It is lightly off-centre from the other circles putting into perspective the accuracy of this 'scientific object';

- The engraver divided the surface between the second circle and the periphery of the curved disc in 3 equal parts of $30^{\circ}$ each. They then defined the perimeter of the instrument by subdividing each of the 12 parts delimited previously into 6 equal graduations (Fig. 6);

- In last step, the inscriptions have been engraved. Indeed the engravings of some letters are above certain lines or circles previously engraved.

- Then this curved disc was probably fixed onto a (spherical?) support, shown through the tin soldering visible on the inferior face of the object. The instrument may have been held in place along the length of its diameter way and on a part of its edge. From a deformation on its lateral part it can be shown that this object may have been extracted from its support when it was discarded (Fig. 7).

The use of the Greek alphabet, the references to Egyptian signs of the Zodiac and Roman months, shows an attempt at making a correspondence between the Egyptian and Roman calendars. Someone with solid knowledge of astrology may have used this rare object. If the practice came from a long tradition, its procedures are very complex to analyse. Finally, future work on archaeological metal at Chevroches will perhaps find other documents related to this disc.

Further important details include:

- Place of manufacturing: the technique of embossing metals is a speciality in Celtic areas, so it could well have been fabricated in Gaul. Patrice Cauderlier (Université de Bourgogne, Ecole Normale Supérieure, Paris), suggests that the object is inspired by an Egyptian model, created in the style of the Alexandrian School, given its use of the Greek language and its abbreviations.

- The date of fabrication: from the epigraphic study (Cauderlier) : end of the 3rd century. 


\begin{tabular}{|c|c|c|c|c|c|}
\hline & Ligne & Inscription & $\begin{array}{l}\text { Lecture de } \\
\text { l'inscription }\end{array}$ & $\begin{array}{l}\text { Interprétation } \\
\text { (P. Cauderlier) }\end{array}$ & $\begin{array}{c}\text { Signification } \\
\text { Traduction }\end{array}$ \\
\hline 01 & $\begin{array}{l}\frac{\text { extérieure }}{\text { médiane }^{*}} \\
\text { intérieure }^{\text {na }}\end{array}$ & $\begin{array}{l}\theta \omega 0 \theta \\
\pi A P \theta \in N \omega \\
c \in \pi I E \mu\end{array}$ & $\begin{array}{c}\theta \omega \theta \\
\text { ПАР } \theta \mathrm{EN} \omega \\
\text { СЕПТЕМ }\end{array}$ & 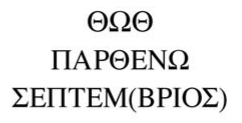 & $\begin{array}{c}\text { Thôt } \\
\text { Vierge } \\
\text { Septembre }\end{array}$ \\
\hline 02 & $\begin{array}{l}\frac{\text { extérieure }}{\text { médiane }^{*}} \\
\text { intérieure }^{\text {na }}\end{array}$ & 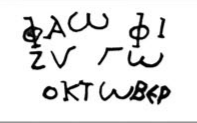 & $\begin{array}{c}\text { ФА } \omega \Phi I \\
\text { ZYГ } \omega \\
\text { OKТ } \omega \text { BEP }\end{array}$ & $\begin{array}{c}\text { ФА } \Omega \Phi \mathrm{I} \\
\mathrm{ZY} \Omega \\
\mathrm{OKT} \Omega(\mathrm{BPIO} \Sigma)\end{array}$ & $\begin{array}{l}\text { Phaôphi } \\
\text { Balance } \\
\text { Octobre }\end{array}$ \\
\hline 03 & $\begin{array}{l}\frac{\text { extérieure }}{\text { médiane * }^{*}} \\
\text { intérieure }\end{array}$ & $\begin{array}{l}P \theta Y P \\
E K i P^{T} / W \\
\text { NOOYEM }\end{array}$ & $\begin{array}{c}\text { AӨYP } \\
\text { CKIPПI } \omega \\
\text { NOOYEM }\end{array}$ & 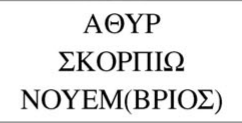 & $\begin{array}{l}\text { Hâthyr } \\
\text { Scorpion } \\
\text { Novembre }\end{array}$ \\
\hline 04 & $\begin{array}{l}\frac{\text { extérieure }}{\text { médiane }^{*}} \\
\text { intérieure }^{\text {intere }}\end{array}$ & $\begin{array}{l}X O \perp A X \\
\text { IOIOTH } \\
X G K G B_{C}\end{array}$ & $\begin{array}{c}\text { XOIAX } \\
\text { TOEOTH } \\
\triangle \text { EKEMBC }\end{array}$ & 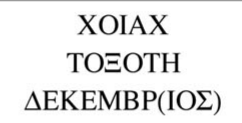 & $\begin{array}{c}\text { Choiak } \\
\text { Sagittaire } \\
\text { Décembre }\end{array}$ \\
\hline 05 & $\begin{array}{l}\frac{\text { extérieure }}{\text { médiane }^{*}} \\
\text { intérieure }\end{array}$ & $\begin{array}{l}\text { IYOBJ } \\
\text { AU OKE } \\
\text { IANOOXP }\end{array}$ & $\begin{array}{c}\text { TYBI } \\
\text { AIГOKE } \\
\text { IANOOYิAP }\end{array}$ & 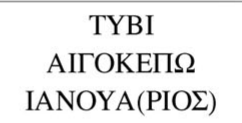 & $\begin{array}{c}\text { Tybi } \\
\text { Capricorne } \\
\text { Janvier }\end{array}$ \\
\hline 06 & $\begin{array}{l}\frac{\text { extérieure }}{\text { médiane }}{ }^{*} \\
\text { intérieure }^{\text {nat }}\end{array}$ & 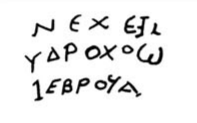 & $\begin{array}{c}\text { ṂEXEIP } \\
\text { Y } \triangle \text { POXO } \omega \\
\Phi ̣ \text { EBPOYA }\end{array}$ & $\begin{array}{c}\text { MEXEIP } \\
\text { Y } \triangle \text { POXO } \Omega \\
\text { ФEBPOY(APIO })\end{array}$ & $\begin{array}{l}\text { Méchir } \\
\text { Verseau } \\
\text { Février }\end{array}$ \\
\hline 07 & $\begin{array}{l}\frac{\text { extérieure }}{\text { médiane * }} \\
\underline{\text { intérieure }}\end{array}$ & 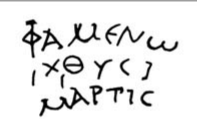 & $\begin{array}{c}\text { ФAMEN } \omega \\
\text { IXӨYCI } \\
\text { MAPTIO }\end{array}$ & 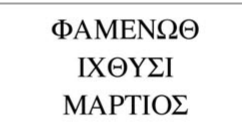 & $\begin{array}{c}\text { Phaménoth } \\
\text { Poissons } \\
\text { Mars }\end{array}$ \\
\hline 08 & $\begin{array}{l}\frac{\text { extérieure }}{\text { médiane }^{*}} \\
\text { intérieure }^{\text {na }}\end{array}$ & $\begin{array}{l}\text { QAPNAOYO } \\
\text { KPI C } \\
A T P \in I A P C\end{array}$ & $\begin{array}{c}\text { ФАРМОY } \\
\text { КРІ } \omega \\
\text { АПРЕІ } А Р C\end{array}$ & 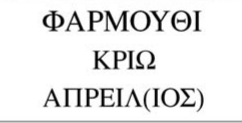 & $\begin{array}{c}\text { Pharmouthi } \\
\text { Bélier } \\
\text { Avril }\end{array}$ \\
\hline 09 & $\begin{array}{l}\frac{\text { extérieure }}{\text { médiane }^{*}} \\
\underline{\text { intérieure }}\end{array}$ & $\begin{array}{l}\text { TTAXCUN } \\
\text { TAYPU } \\
\text { WAI OYC }\end{array}$ & $\begin{array}{c}\text { ПAX } \omega N \\
\text { TAYP } \omega \\
\text { MAÏOYC }\end{array}$ & $\begin{array}{c}\text { ПАХ } \Omega N \\
\text { TAYP } \Omega \\
\text { MAÏOY } \Sigma\end{array}$ & $\begin{array}{c}\text { Pachôn } \\
\text { Taureau } \\
\text { Mai }\end{array}$ \\
\hline 10 & $\begin{array}{l}\frac{\text { extérieure }}{\text { médiane * }} \\
\text { intérieure }\end{array}$ & $\begin{array}{l}\text { ITAYNI } \\
\Delta I \Delta Y M O I \\
\text { TOY OC }\end{array}$ & $\begin{array}{c}\text { ПAYNI } \\
\Delta \mathrm{I} \Delta \mathrm{YMOI} \\
\mathrm{IOY}[\mathrm{OOC}\end{array}$ & 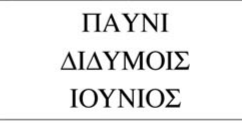 & $\begin{array}{l}\text { Payni } \\
\text { Gémeaux } \\
\text { Juin }\end{array}$ \\
\hline 11 & $\begin{array}{l}\frac{\text { extérieure }}{\text { médiane }}{ }^{*} \\
\text { intérieure }\end{array}$ & $\begin{array}{l}E \Pi \in I \Phi \\
\text { KAPKING } \\
\text { IOVAIOC }\end{array}$ & $\begin{array}{c}\text { ЕПЕІФ } \\
\text { KAPKIN } \omega \\
\text { IOY } \Lambda \text { IOC }\end{array}$ & 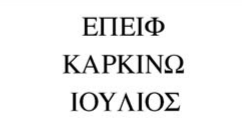 & $\begin{array}{l}\text { Epiph } \\
\text { Cancer } \\
\text { Juillet }\end{array}$ \\
\hline 12 & $\begin{array}{l}\frac{\text { extérieure }}{\text { médiane * }} \\
\text { intérieure }\end{array}$ & $\begin{array}{l}\text { UE COPH } \\
\text { XEONII } \\
\text { AYPOYCI }\end{array}$ & $\begin{array}{c}\text { MECOPH } \\
\Lambda \text { EONTI } \\
\text { АҮГОҮCT }\end{array}$ & $\begin{array}{c}\text { ME } \Sigma O P H \\
\Lambda \text { EONTI } \\
\text { АҮГОY }(\Sigma T O \Sigma)\end{array}$ & $\begin{array}{l}\text { Mésoré } \\
\text { Lion } \\
\text { Août }\end{array}$ \\
\hline
\end{tabular}

Ligne extérieure : mois égyptien (Thôt est le $1^{\text {er }}$ mois de l'année égyptienne)

Ligne médiane au datif : signe zodiacal

* : sans iôta adscrit

Ligne intérieure : mois romain

Claudine Magister Vernou

Figure 4. Transcription of the inscriptions by P. Cauderlier \& C. Magister-Vernou (2006).

- The date of burying: the stratigraphic context : 340 / 350 . 

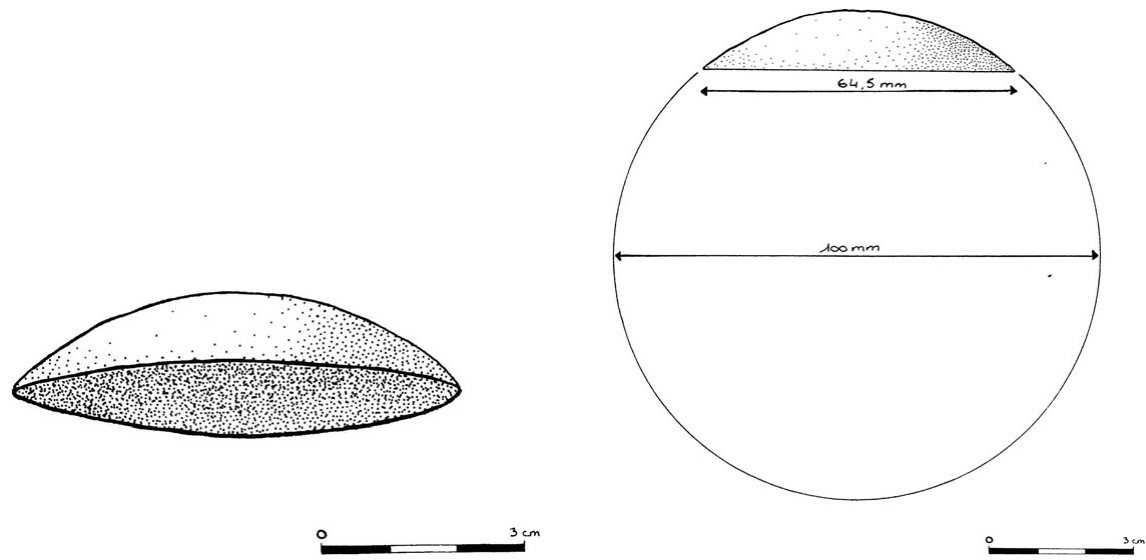

Figure 5. Phases 1 and 2 of the manufacturing process (C. Magister-Vernou/MAD 2006).
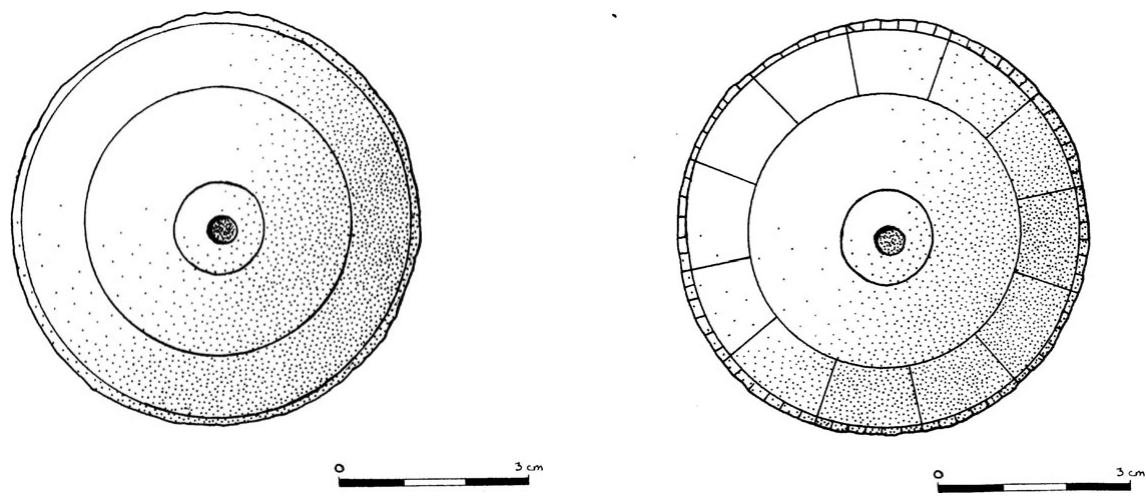

Figure 6. Phase 3 of the manufacturing process (C. Magister-Vernou/MAD 2006).
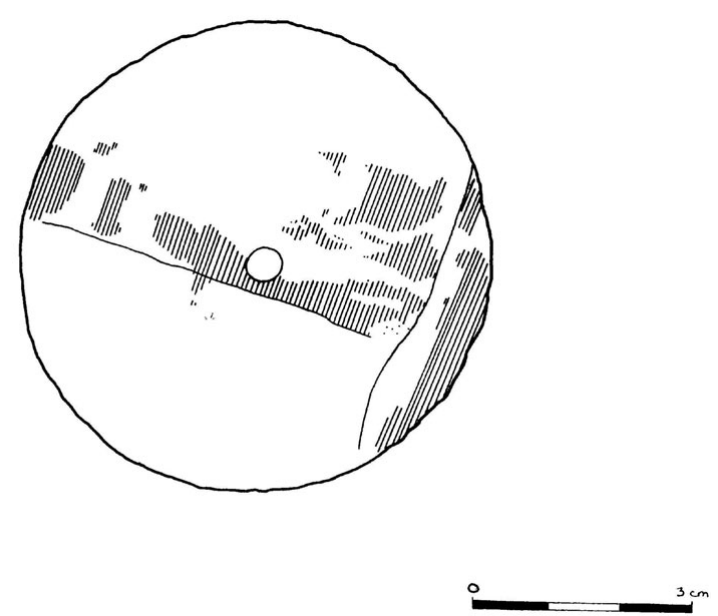

Figure 7. The other side of the disc (C. Magister-Vernou/MAD 2006).

\section{Possible usages}

\subsection{Hypothesis 1: an astrological device}

The astrologer began by overlaying his map of the sky (drawn on papyrus or on a wooden tablet for example) with the ecliptic's median plan (oriented on the top of the sky), and 
then he installed two signs of the Zodiac. With the help of tables (such as the widely used Theon's tables), he determined the middle and the bottom of the sky, and then he established the position of the planets by looking at his map. By rotating the table by $180^{\circ}$, he wrote the name of the zodiacal signs. With an instrument like the curved disc of Chevroches, the astrologer could transfer the data of the day to establish his customer's horoscope or to look up the positive and negative dates (very much like the Tryphon's horoscope kept at the University of Oxford, cf. Neugebauer \& Van Hosen 1959). The practice of this discipline, however, is complex and requires the assimilation of specific notions, which would take too long to develop in this paper. This astrological (?) curved disc is indeed extraordinary; it seems to be a unique object of its type in the ancient world. However, other testimonies of astrological practices during the Roman period are attested, and among these stands out two folding ivory diptychs found in the Grand site (Vosges, France) by J.-P. Berteaux and the end of the 1960s. These diptychs show a sky map organised in Zodiacs where the figures are emphasised in the dimple, by red, black and gold (Buisson \& Abry 1993).

\subsection{Hypothesis 2: an element of a complex mechanism}

This mechanism could be used for astronomical issues, to calculate and predict the movement of planets for instance. The traces of tin soldering on the curved disc entices us to think about a more complex mechanism, which could be related to the Chevroches curved disc, known as the Alesia diary (Espérandieu 1933). This object is a thin circular bronze slab of $11 \mathrm{~cm}$ in diameter discovered in 1933 in an excavation at Alise Sainte Reine (Burgundy). It was conserved at the Palais du Roure collection, in Avignon. Recently we (C. Vernou and C. Magister) studied it and found that one can see 7 characters engraved on it, which correspond to the 7 days of the week: 1- the Moon, 2- Mars, 3- Mercury, 4- Jupiter, 5- Venus, 6- Saturn, 7- the Sun or Apollo. We also notice 37 hatched triangles and 37 smooth triangles, which according to P. Cauderlier would correspond to the decans of the nights and days (Fig. 8). This representation seems like the front plate of a Byzantine sundial-calendar, from the end of the 5th century, conserved at the Science Museum of London (Field \& Wright 1985).

There are also similarities with another astronomical artefact, recently re-discovered. C. Vernou -whilst searching for similar objects found in the region since the 19th centuryfound a drawing of a curious object coming from the Roman sanctuary built at the source of the Seine river (Baudot 1842-1846). It is a disc cut into 14 nicks, pierced in the centre, and where the name of the 7 planets is engraved face to face (Fig. 9). The planets are indicated by the three first letters of the deities corresponding to the 7 weekdays. We can read (from right to left): Iun (ae) or Diana, mar (tis), mer (cury), iov (is), ven (eris), sat (urnus), sol (is) or Apollo. This diary was probably positioned to see one name at a time (in a small window ?), and each name was replaced by another name, by turning the "disc" on its axis. It reminds on the arbor with ratchet from the Byzantine sundialcalendar conserved at the Science Museum (Field \& Wright 1985, plate 6, p. 31).

This object from Dijon will soon be exhibited and published over 150 years after its discovery.

\subsection{Hypothesis 3: an element of armillary sphere / globe / anaphoric clock}

There are only three celestial globes which survive from Greco-Roman times. All three globes reproduce all or most of the constellations known in Greco-Roman culture. These are: the well-known Farnese Globe, the Mainz Globe; and the recently-discovered Kugel Globe (Cuvigny 2004). Of these only the Farnese Globe is a large globe. Both the Mainz Globe and the Kugel Globe are miniature globes (part of armillary spheres?). Debo- 


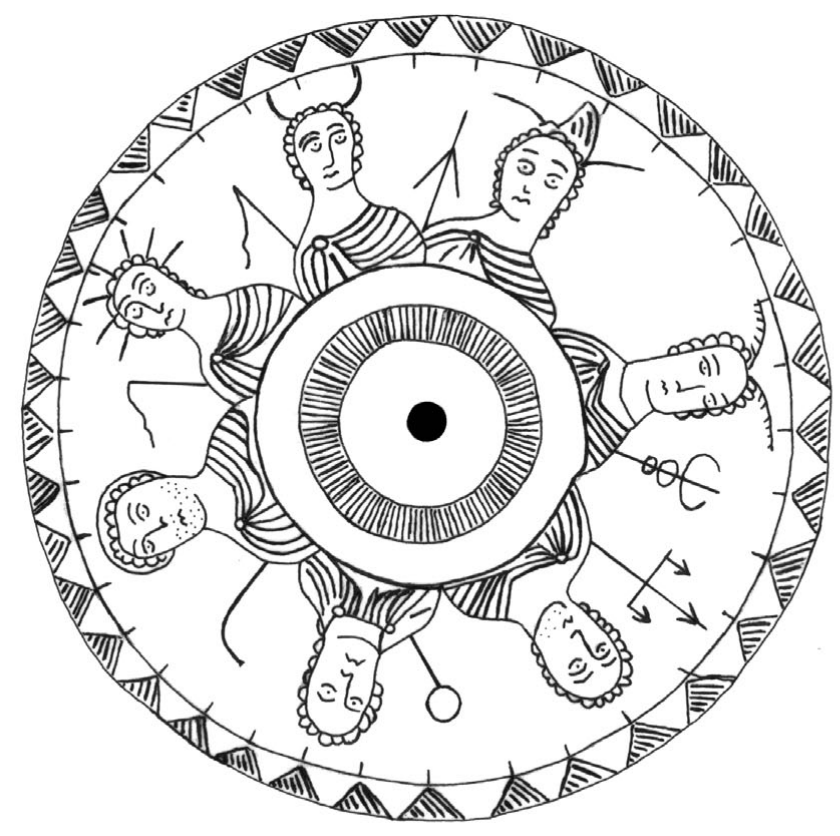

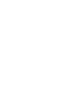




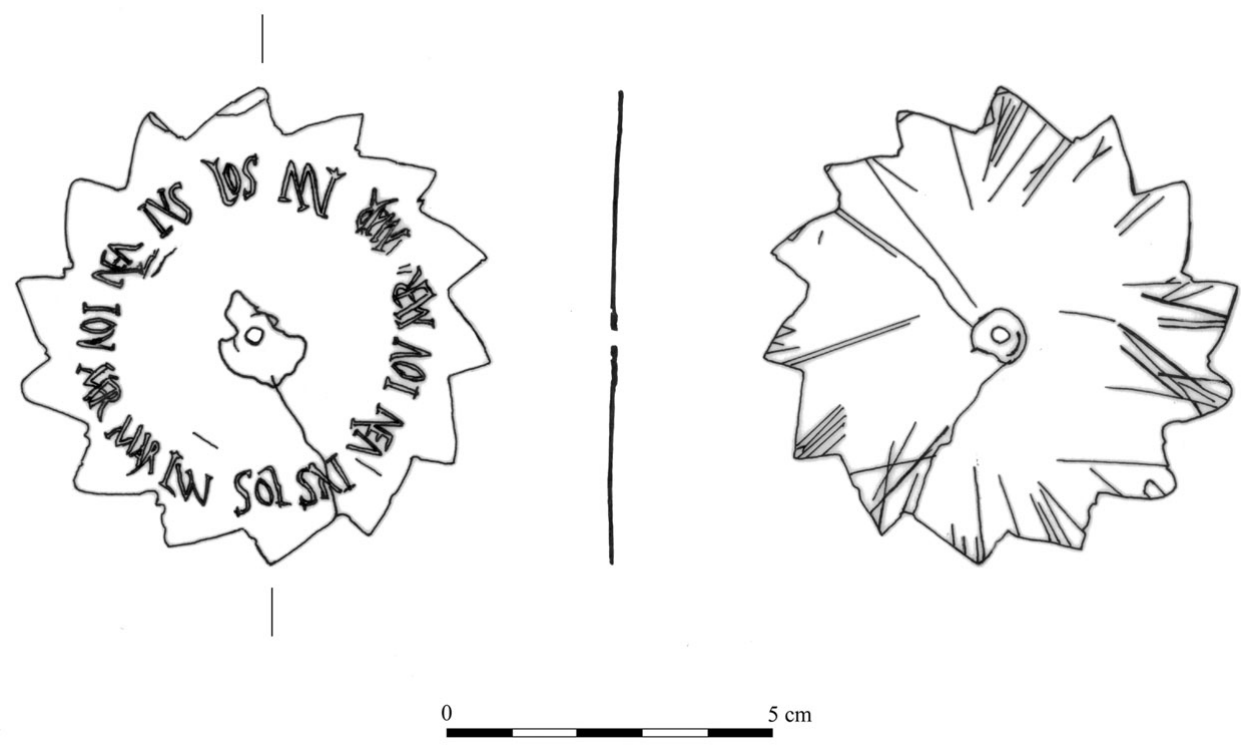

Figure 9. The double Semainier from the sources of the Seine river (C. Magister-Vernou/MAD 2008).

\section{References}

Buisson, A. \& Abry, J.H. 1993, Actes de la table ronde du 18 mars 1992, Université de Lyon III, Coll. du Centre d'études romaines et gallo-romaines, nouvelle série, Vol. 12, (Paris:De Boccard), p. 77

Baudot, H. 1842-1846, Mémoires de la Commission des Antiquités de la Côte-d'Or, 2, 95

Berteaux, J.-P. \& Gury, F. 1990, in La Lorraine antique : villes et villages, 30 ans d'archéologie (Moulins-les-Metz: Est Imprimerie) p. 150

Cuvigny, H. 2004, Gedenschrift Ulrike Horak, H. Harrauer \& R. Pintaudi (eds), Papyrologica florentina, 34, (Firenze: Gonnelli), p. 345

Devevey, F. 2005, Chevroches, Le domaine de Noé, Rapport Final d'Opérations (Sennecey-lèsDijon: INRAP)

Devevey, F., Cauderlier, P., Magister-Vernou, C. \& Vernou, C. 2006, Revue Archéologique de l'Est, 55, 299

Espérandieu, E. 1933, Comptes-rendus de l'Académie des Inscriptions et Belles-Lettres, 77, 337

Field, J.V., \& Wright, M.T. 1985, Early Gearing. Geared Mechanisms in the Ancient and Medieval World (London: Science Museum)

Neugebauer, O. \& Van Hosen, H.B. 1959, Greek horoscopes, Memoirs of the American Philosophical Society, 48 (Philadelphia: The American Philosophical Society)

Warner, D.J. 1979, The Sky explored : celestial cartography, 1500-1800 (New York/Amsterdam: A.R. Liss/Theatrum orbis terrarum) 